\title{
ARTICLE
}

\section{Cell wall precursors are required to organize the chlamydial division septum}

Nicolas Jacquier ${ }^{1}$, Antonio Frandi ${ }^{2}$, Trestan Pillonel ${ }^{1}$, Patrick H. Viollier ${ }^{2}$ \& Gilbert Greub ${ }^{1}$

Members of the Chlamydiales order are major bacterial pathogens that divide at mid-cell, without a sequence homologue of the FtsZ cytokinetic tubulin and without a classical peptidoglycan cell wall. Moreover, the spatiotemporal mechanisms directing constriction in Chlamydia are not known. Here we show that the MreB actin homologue and its conserved regulator RodZ localize to the division furrow in Waddlia chondrophila, a member of the Chlamydiales order implicated in human miscarriage. RodZ is recruited to the septal site earlier than MreB and in a manner that depends on biosynthesis of the peptidoglycan precursor lipid II by the MurA enzyme. By contrast, crosslinking of lipid II peptides by the $\mathrm{Pbp} 3$ transpeptidase disperses RodZ from the septum. Altogether, these findings provide a cytological framework for understanding chlamydial cytokinesis driven by septal cell wall synthesis.

\footnotetext{
${ }^{1}$ Institute of Microbiology, University Hospital Center and University of Lausanne, 1011 Lausanne, Switzerland. ${ }^{2}$ Institute of Genetics \& Genomics in Geneva (iGE3), Department of Microbiology \& Molecular Medicine, Faculty of Medicine / CMU, University of Geneva, 1211 Genève 4, Switzerland. Correspondence and requests for materials should be addressed to G.G. (email: gilbert.greub@chuv.ch).
} 
F undamental to proliferation of all cells, the molecular basis of cell division in Chlamydiales is still largely uncharted territory. While several proteins that are essential for division in other bacteria are not encoded in the chlamydial genomes, functional studies on chlamydial cell division are hampered by their poor genetic tractability and their obligate intracellular lifestyle. The Chlamydiae are composed of the members of the Chlamydiaceae family and of several other family-level lineages coined 'Chlamydia-related bacteria'. Chlamydiaceae include major human pathogens: C. trachomatis causes urogenital infections and trachoma; C. pneumoniae and C. psittaci cause pneumonia ${ }^{1}$. Waddlia chondrophila, another member of the Chlamydiales order, is implicated in abortion in bovines $^{2}$ and in miscarriage in humans ${ }^{3-5}$. Like other Chlamydiae, W. chondrophila is a strict intracellular bacterium that exhibits two developmental states: infectious non-dividing elementary bodies (EBs) and non-infectious dividing reticulate bodies $(\mathrm{RBs})^{6-8}$. When EBs enter cells, they reside in a vacuole called inclusion. Next, they differentiate into RBs, decondensing their genome and initiating transcription and replication. Finally, RBs redifferentiate into EBs that are expelled by exocytosis or cell lysis ${ }^{8}$.

W. chondrophila represents an ideal model for cytological studies on Chlamydiae. W. chondrophila can infect and proliferate in a range of cells, including amoebae, human macrophages, Vero cells, pneumocytes, endometrial cells and fish cell lines ${ }^{9-12}$, presumably because of the larger metabolic capacity encoded in its genome versus that of Chlamydiaceae ${ }^{13}$. Moreover, Waddlia cells are bigger than those of Chlamydiaceae and thus better suited for protein localization studies underlying chlamydial cell division.

Unlike Chlamydiaceae, $W$. chondrophila is resistant to many $\beta$-lactam antibiotics ${ }^{10}$ that target the bacterial cell wall (peptidoglycan). Peptidoglycan (PG) is a polymer of glycan strands assembled from $\mathrm{N}$-acetyl-glucosamine and $\mathrm{N}$-acetylmuramic acid through $\beta$-(1,4)-glycosidic bonds and stabilized through peptide bridges containing D-amino acids. While it protects cells from lysis in hypo-osmotic conditions and endows cells with their characteristic shape, it also plays an important role in cell division as PG synthesis at the division septum (septal PG) can direct the invagination of the cytoplasmic membrane ${ }^{14}$.

Recently, PG has been biochemically detected in Chlamydiae, and circumstantial evidence suggests that PG-like material resides at the chlamydial division septum ${ }^{15,16}$. Moreover, functional homologues of PG biosynthesis enzymes are encoded in chlamydial genomes ${ }^{17-21}$. Septal PG is likely produced in low amounts, in a modified form and/or only transiently during constriction, explaining why it is difficult to detect by conventional biochemical techniques. Antibodies raised against mycobacterial cell wall skeleton detect a septal non-proteinaceous antigen, likely a derivative of $\mathrm{PG}^{22}$, in dividing Chlamydiae. The apparent absence of coding sequences for enzymes that typically catalyse the polymerization of the glycan strands, suggests that Chlamydiae might, alternatively, polymerize a modified PG structure composed exclusively of crosslinked peptide bridges without a glycan component ${ }^{18}$. Nevertheless, penicillin-binding protein $(\mathrm{Pbp})$ homologues that are responsible for the transpeptidation of neighboring penta-peptide bridges are encoded in Chlamydiae, and penicillin inhibits division and induces the formation of large abnormal RBs, called aberrant bodies ${ }^{23}$. Aberrant bodies may result from continued DNA replication without division, the counterpart of filamentous cells arising when division of rod-shaped bacteria is inhibited by penicillin. Importantly, aberrant bodies are involved in the persistence of chlamydial infections and are also induced by iron or nutrient starvation or by IFN-gamma treatment ${ }^{23-26}$. When stress is relieved, aberrant bodies divide into RBs, which can further differentiate into $\mathrm{EBs}^{27}$, indicating that viability is maintained to a certain degree when division is inhibited.

In most bacteria, septal PG synthesis is organized by the FtsZ division protein, a tubulin homologue that polymerizes into a membrane-associated contractile ring at the future division site and that recruits cell division proteins including the PG biosynthetic machine. The FtsZ (Z-) ring can also invaginate the cytoplasmic membrane, at least in vitro ${ }^{28}$. Remarkably, Chlamydiae divide by binary fission ${ }^{7-9,22}$ in the absence of a FtsZ sequence homologue ${ }^{13,29}$. Furthermore, the $C$. trachomatis genome has only three annotated cell division genes: ftsI (encoding $\mathrm{Pbp} 3$ ), ftsK and $f t s W$, whereas the $W$. chondrophila genome encodes sequence homologues of $f t s I, f t s K, f t s L$, fts $Q$ and ftsW. Although Chlamydiae lack FtsZ, they do encode homologues of the MreB actin and its regulator RodZ, known to be involved in cell shape control by regulating PG synthesis in rod-shaped bacteria ${ }^{30}$. Importantly, a functional and cytological relationship between RodZ and the cytokinetic Z-ring has been described ${ }^{31-34}$

In the absence of a FtsZ-cytoskeleton, Chlamydiae might rely on MreB and/or RodZ to organize division. Since MreB can polymerize in vitro, it is a good candidate to act as a cytoskeletal element that could organize chlamydial division ${ }^{35}$. Several MreB interactors were described; FtsK directly interacts with the C. trachomatis MreB (in a bacterial two-hybrid (BACTH) assay $^{36}$ ), MreC interacts with a MreB homologue in Bacillus subtilis ${ }^{37}$ and with RodZ, which was shown to anchor MreB to the membrane in $E$. coli $i^{38}$ and which is uncharacterized in Chlamydiales $^{39}$. Moreover, E. coli MurG, a component of the PG biosynthesis pathway, also interacts with $\mathrm{MreB}^{40}$ and Chlamydia pneumoniae MreB interacts with MurG and MraY by BACTH assay and with MurF in an in vitro cosedimentation assay $^{35}$. However, the spatial relationship between these factors and the chlamydial division septum remains unexplored.

Here, we show that MreB and RodZ are localized to the division septum in $W$. chondrophila RBs. Interestingly, septal localization of $\operatorname{RodZ}$ precedes that of MreB and is dependent on the function of MurA, a critical enzyme of the PG biosynthesis pathway, which can be inhibited by the phosphonic antibiotic phosphomycin. RodZ is enriched at mid-cell upon penicillin treatment, indicating that $\operatorname{Rod} Z$ is an early component of the septum, which then recruits other components of the division machinery, possibly MreB, which may provide the driving force for the final stages of division before $\mathrm{Pbp} 3$ disperses RodZ. Taken together, our data highlight the important role of PG derivatives or precursors in organizing chlamydial division septum.

\section{Results}

Primary structure and function of chlamydial MreB. Bioinformatics revealed that chlamydial MreBs exhibit 51.8-59.3\% identity with the orthologues of Escherichia coli, Thermotoga maritima and Caulobacter crescentus. Moreover, as many as $92.3 \%$ of the known active site residues ${ }^{41}$ were conserved in all six species investigated, whereas only $33.8 \%$ of the complete MreB sequences were conserved $(P<0.001$, supplementary Fig. 1A), and important features that were shown to be required for MreB interaction with the bacterial membrane, an amphipathic $\mathrm{N}$-terminal helix and a hydrophobic hairpin, are also conserved among all Chlamydiales ${ }^{42}$ (Supplementary Fig. 1A). Consistent with the notion that chlamydial MreB has MreB-like functional properties, we observed that overexpression of $W$. chondrophila MreB $\left(\mathrm{MreB}^{W c}\right)$ in wild-type $C$. crescentus induced a lemonshape', a loss of crescent shape and swelling of the cell similar to that caused by depletion of MreB from Caulobacter $\left(\mathrm{MreB}^{\mathrm{Cc}}\right)$ 
(Supplementary Fig. 1B) ${ }^{33}$. While MreB ${ }^{W c}$ could not substitute for $\mathrm{MreB}^{\mathrm{Cc}}$, the trans-dominance suggests that $\mathrm{MreB}^{\mathrm{Wc}}$ can interfere with $\mathrm{MreB}^{\mathrm{Cc}}$

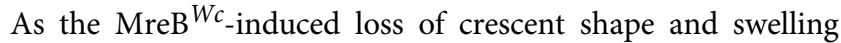
resembles those of $C$. crescentus cells following treatment with the MreB inhibitors, A22 and MP265 (ref. 43), we explored the effect of A22 and MP265 on W. chondrophila and C. pneumoniae. As A22 and MP265 might disturb the host cell cytoskeleton because of the homology between MreB and actin, we tested the effect of actin and tubulin inhibitors cytochalasin D and nocodazole on Waddlia growth. These compounds are toxic for the host cell (Supplementary Fig. 1C) but do not inhibit proliferation of W. chondrophila (Supplementary Fig. 1D,E). While A22 or MP265 have minor toxic side-effects on Vero and Hep-2 host cell (Supplementary Fig. 1C), division and replication of $W$. chondrophila in Vero cells and of C. pneumoniae in Hep-2 cells were impaired after administering either drug at $2 \mathrm{~h}$ postinfection (p.i.) (Fig. 1a and Supplementary Fig. 1F). Consistent with our findings, inhibitors of MreB disturb infection by Chlamydia trachomatis ${ }^{36}$. We cannot exclude that this growth defect is partially due to toxicity of the drugs towards the host cell, but more than $80 \%$ of the host cells were still viable at a dose that inhibited the bacterial growth by $99 \%$. Moreover, we observed the presence of aberrant bodies in cells treated with MP265 for both W. chondrophila and C. pneumoniae (Fig, 1b,c, arrows and Supplementary Fig. 2A). Addition of the drugs at 12 and $24 \mathrm{~h}$ p.i. caused a rapid block of $W$. chondrophila proliferation (Supplementary Fig. 2B-E), indicating that the drugs likely do not affect the bacteria at a specific step of bacterial infection such as entry, differentiation or exit of the bacteria but likely act on bacterial division. Moreover, mitochondrial recruitment $8 \mathrm{~h}$ p.i. was not prevented by these drugs as shown by Mitotracker staining (Supplementary Fig. 2F). Interestingly, when the drugs were added $2 \mathrm{~h}$ p.i. and removed $24 \mathrm{~h}$ p.i., Waddlia replicated again by budding from aberrant bodies (Supplementary Fig. 2I, arrows), showing that A22 and MP265 are bacteriostatic (Supplementary Fig. 2G,H).

Localization of MreB and RodZ to the division septum. To determine the subcellular localization of MreB and its potential regulators/interactors FtsK, FtsQ, MreC and RodZ, we raised antibodies against recombinant $\mathrm{His}_{6}$-tagged variants purified from E. coli. Of these candidates, only RodZ and MreB showed an expression and localization consistent with a cytokinetic role (Supplementary Fig. 3A). Both antisera recognize a single protein of the expected size by immunoblotting (Supplementary Fig. 3B), and biochemical fractionation experiments by ultracentrifugation followed by immunoblotting showed the protein to reside in the predicted subcellular compartments. MreB is present both in the membrane (insoluble) and cytoplasmic (soluble) fraction, consistent with the known partitioning properties of monomeric and polymeric MreB, respectively. By contrast, RodZ partitioned exclusively to the membrane fraction, consistent with the C-terminal membrane spanning fragment predicted for residues 110-128 of RodZ (Supplementary Fig. 3C). Quantitative reversetranscriptase PCR (qRT-PCR) measurements revealed a peak of $m r e B$ and rodZ transcripts between 8 and $24 \mathrm{~h}$ p.i. but otherwise constant expression (Fig. 2a). Indeed, immunoblotting (Fig. 2b) and immunofluorescence microscopy (Fig. 2c) showed that MreB and RodZ are present throughout the developmental cycle, although RodZ abundance in EBs (discernible from RBs by virtue of their condensed nucleoid) appeared reduced by immunofluorescence (Fig. 2c, arrows).

To determine the localization of these proteins during division, we observed dividing bacteria $28 \mathrm{~h}$ p.i., a time at which RBs are a
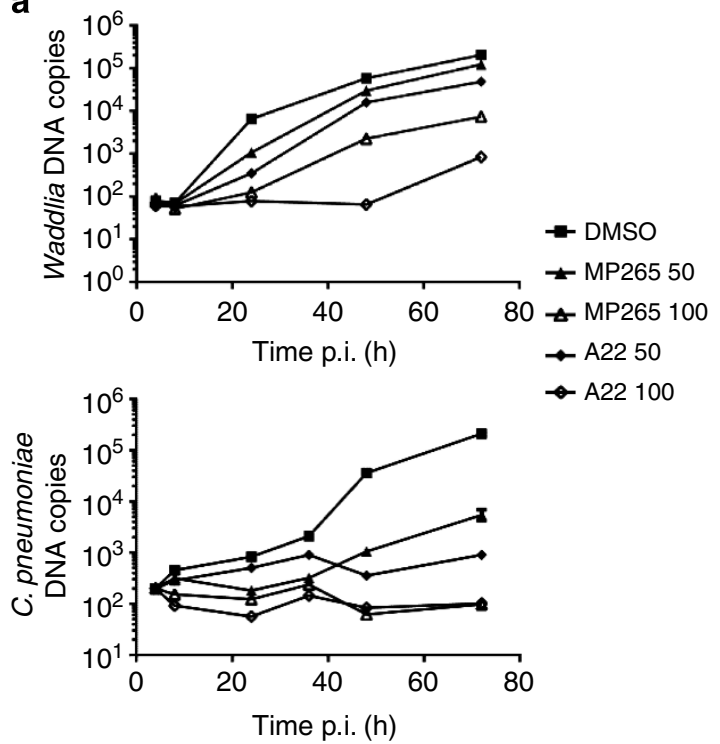

b W. chondrophila
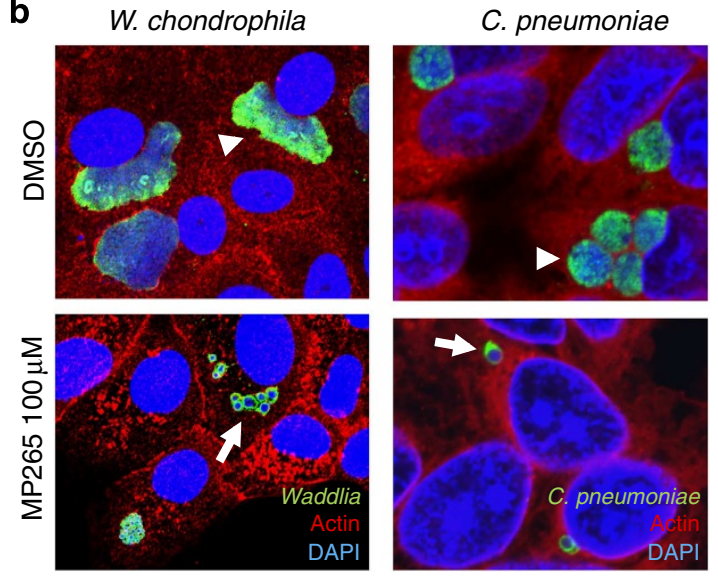

C
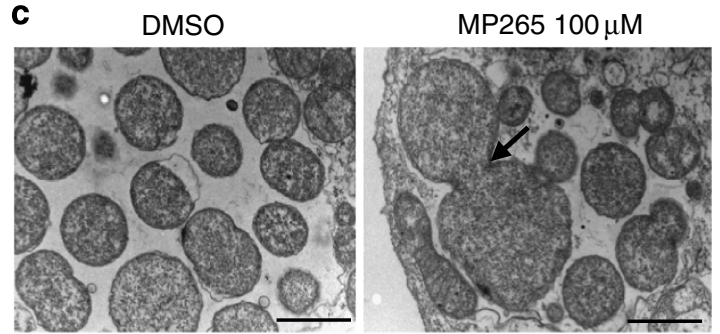

Figure 1 | MreB inhibition blocks chlamydial infection and induces aberrant bodies formation. (a) DNA replication rate is lower in presence of the MreB inhibitors. Vero cells (resp. Hep-2 cells) were harvested at different time points after infection with W. chondrophila (resp. C. pneumoniae) with or without treatment with A22 or MP265 (50 or $100 \mu \mathrm{M}$ ), DNA was extracted and W. chondrophila (resp. C. pneumoniae) DNA was quantified by qPCR. (Error bars represent the s.d. of three independent experiments). (b) Treatment of $W$. chondrophila with MreB inhibitors induces the formation of aberrant bodies. Infected Vero cells (resp. Hep-2 cells) were fixed and stained with anti-Waddlia antibodies (resp. anti-chlamydial LPS antibodies), anti-Actin antibodies and DAPI. Confocal microscopy was performed $48 \mathrm{~h}$ p.i. in absence or presence of MP265. Normal inclusions filled with dividing RBs are pointed by arrowheads, whereas enlarged non-dividing aberrant bodies are pointed by arrows. (c) Aberrant bodies of $W$. chondrophila observed by electron microscopy. Infected Vero cells were treated with MP265 $2 \mathrm{~h}$ p.i. Cells were harvested $24 \mathrm{~h}$ p.i., fixed and prepared for EM as described. The arrow points the presence of an aborted invagination at the mid-cell (Scale bar, $1 \mu \mathrm{m}$ ). 
dividing but no redifferentiation to EBs is visible. We classified the dividing bacteria into early, medium or late dividing cells depending on the morphology of the septum (open septum for early, closed septal band for medium and a single septal focus for late, Fig. 3a). We observed MreB to be enriched at the division septum only at medium and late division stages (Fig. 3b,d). To exclude that this fluorescence signal is due to MreB in juxtaposed neighbouring cytoplasmic membranes of the two daughter cells, we quantified the fluorescence signal along dividing cells. We observed an increase in the MreB fluorescence signal at the septum compared with the fluorescence signal obtained with the polyclonal polyspecific antibodies directed against all immuno- genic Waddlia proteins ('total' anti-Waddlia, Fig. 3d lines 1-3). Moreover, quantification of signals along the division septum shows a different distribution of MreB compared with that of total anti-Waddlia signal (Fig. 3d, lines 4-6). Taken together, the septal signal stemming from the anti-MreB antibody exceeds that from the other antibodies including the total anti-Waddlia, antiFtsQ, anti-FtsK and anti-MreC antibodies.

Strikingly, while MreB is a late recruit to the division septum, RodZ localizes to the septum early during division (in more than $80 \%$ of early dividing cells, Fig. 3c). Quantification of the fluorescence signal from the anti-RodZ antibody along the longitudinal (Fig. 3e, lines 1-3) and transversal axes (Fig. 3e,

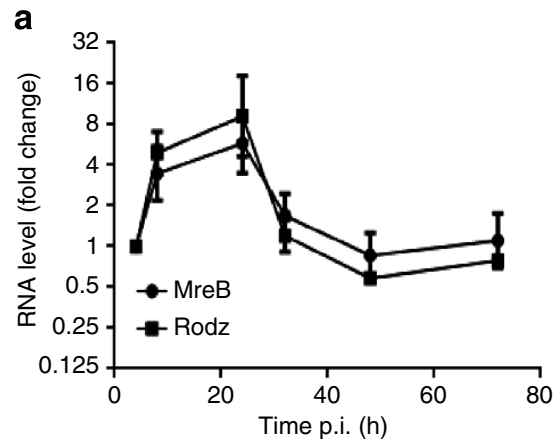

b

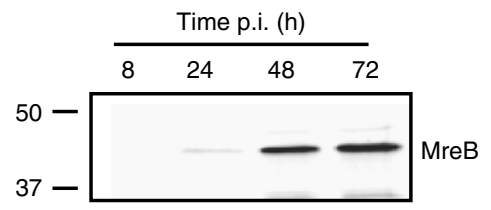

(kDa)

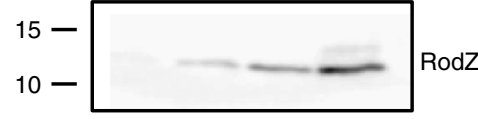

$8 \mathrm{~h}$

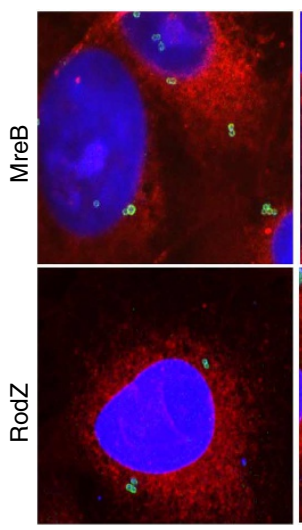

$24 \mathrm{~h}$

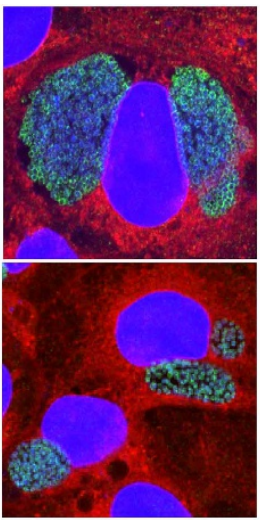

$48 \mathrm{~h}$

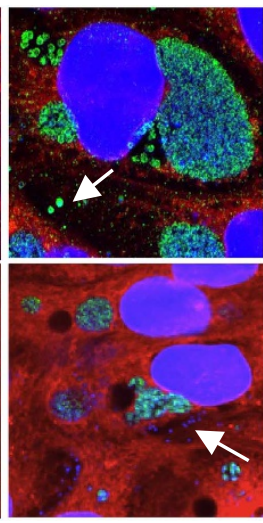

$72 \mathrm{~h}$

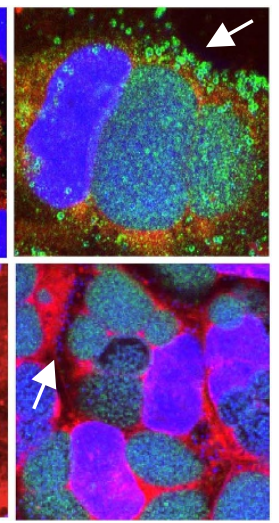

Figure 2 | MreB and RodZ are synchronously expressed, but RodZ does not accumulate in EBs. (a) RNA expression of MreB and RodZ are synchronous. Vero cells were infected with $W$. chondrophila, and samples were taken at the indicated time points. RNA was extracted, cDNA was synthesized and quantified by qPCR as described (Error bars represent the s.d. of three independent experiments). (b) Antibodies against MreB and RodZ are specific. Similar samples as for $\mathbf{a}$ were taken and proteins were extracted. Proteins were then detected by western blot with antibodies raised against purified MreB or RodZ. (c) MreB protein is detectable in both EBs and RBs but RodZ only in RBs during the developmental cycle. Vero cells infected with W. chondrophila were fixed at the given time points and labelled with an anti-MreB antibody (green), concanavalin A (red) and DAPI (blue) and observed by confocal microscopy. Arrows point to extracellular EBs, which can be recognized thank to their condensed DNA.

Figure 3 | RodZ accumulates at the division septum earlier during division than MreB. (a) Dividing W. chondrophila are classified into three groups: early, medium and late division. Vero cells were infected with $W$. chondrophila, fixed $28 \mathrm{~h}$ post-infection and labelled with a total anti-Waddlia antibody and DAPI. Dividing bacteria were then observed and quantified by confocal microscopy $(N=200)$. (b) MreB localizes at the division septum only during medium and late dividing stages. Infected cells were treated as in a but labelled with anti-MreB antibodies (green) and total anti-Waddlia antibodies (red) and quantified by confocal microscopy $(N=100)$. (c) RodZ localizes at the division septum early during division. Infected cells were treated as in a but labelled with anti-RodZ antibodies (green) and total anti-Waddlia antibodies (red) and quantified by confocal microscopy $(N=100)$. (d) Observation of dividing W. chondrophila by confocal microscopy shows different MreB-containing structures: line (arrows) and distinct punctuae (arrowheads). Quantification of the fluorescence along the described axes (1-6) was performed using Image J software and shown in the corresponding graphs. Longitudinal quantification showed an enrichment of MreB at the dividing plane compared with the total Waddlia signal (1-3). Transversal quantification along the division septum showed one or two peaks of MreB fluorescence, consistent with a Z-ring structure (4-6). (e) Quantification of the enrichment of RodZ at the division site. The same procedure as in $\mathbf{d}$ was performed with an antibody against RodZ. Longitudinal quantification (1-3) showed an enrichment of RodZ at the division septum. Transversal quantification (4-6) shows two peaks characteristic of a Z-ring structure. 
lines 4-6) in dividing cells is consistent with a specific septal localization, rather than a diffuse localization in the membrane. Importantly, the total anti-Waddlia antibody did not yield septal staining at this time (Fig. 3e, lines 1 and 2). Later, in deeply constricted cells, both RodZ and MreB show a similar focal enrichment at the septum (Fig. 3d lines 1-3 and Fig. 3e line 3).

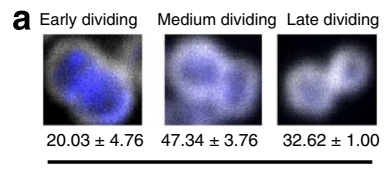

(\% Of dividing cells)

d
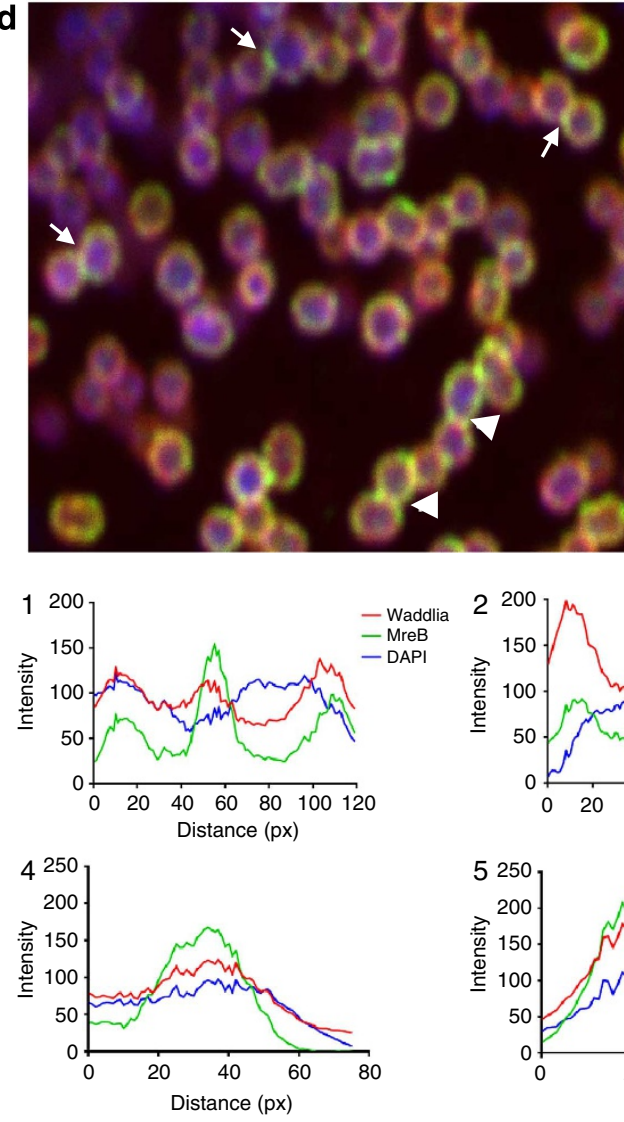

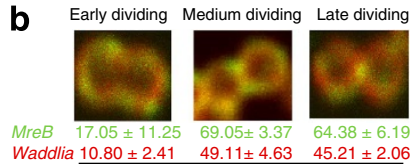

(\% Of dividing cells with septal protein accumulation)

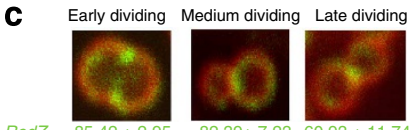

Waddlia $20.83 \pm 5.89 \quad 69.89 \pm 10.45 \quad 64.77 \pm 17.18$ (\% Of dividing cells with septal protein accumulation)
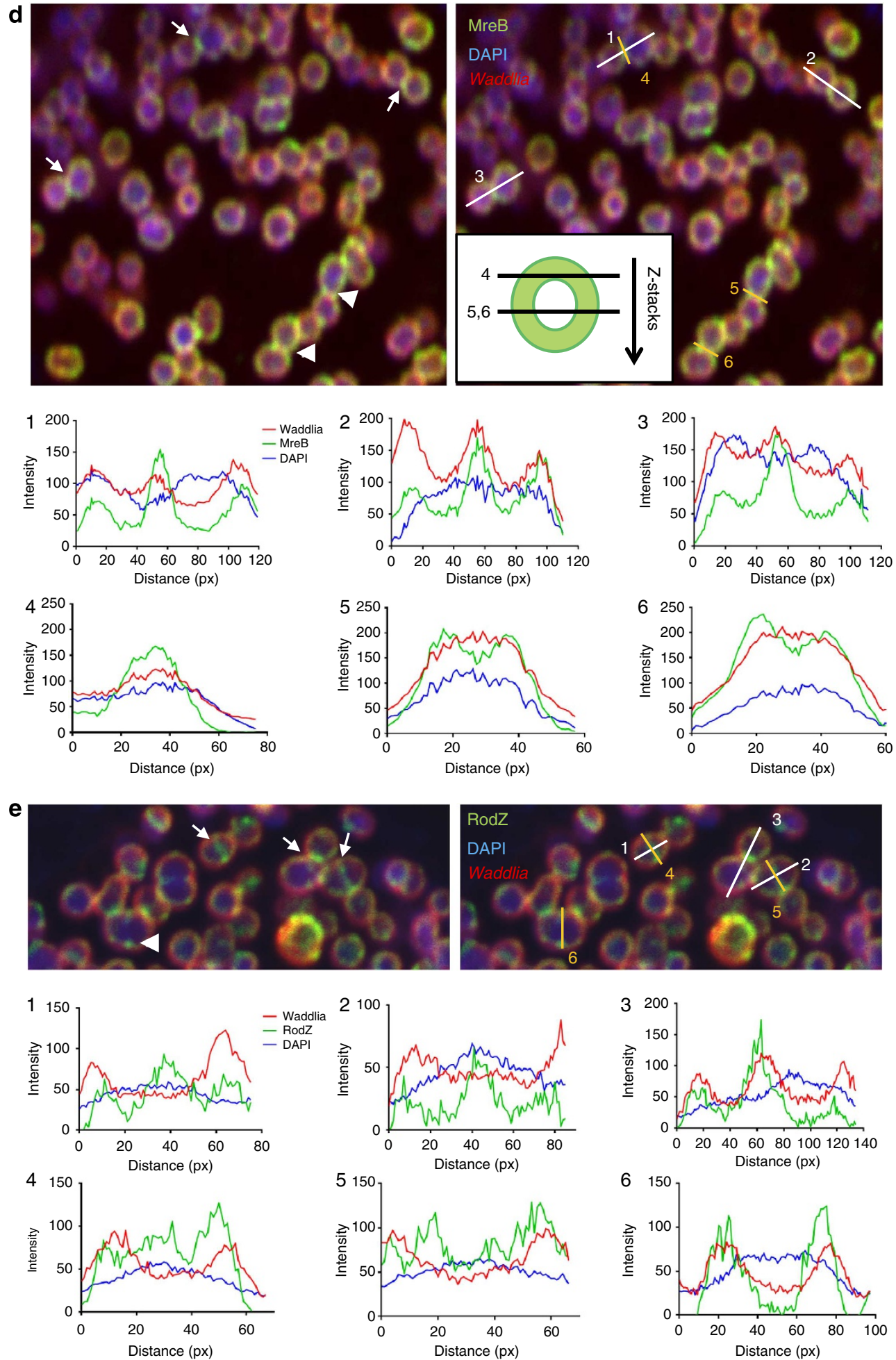
These findings provide strong evidence that RodZ is an early septal protein, while $\mathrm{MreB}$ is recruited to the septum only in deeply constricted cells.

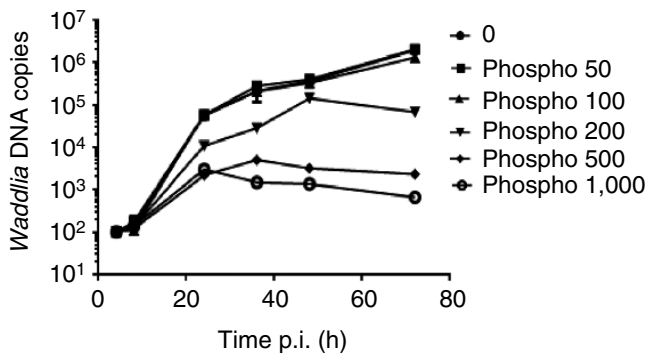

b

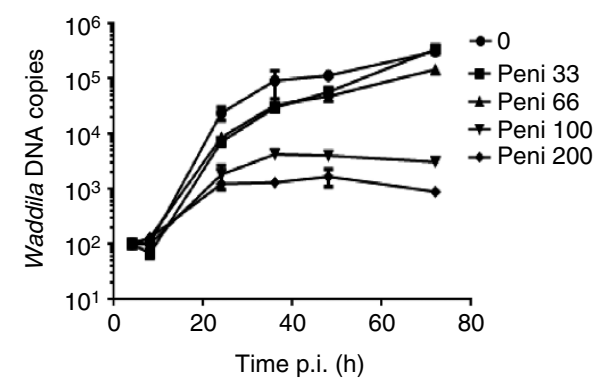

C

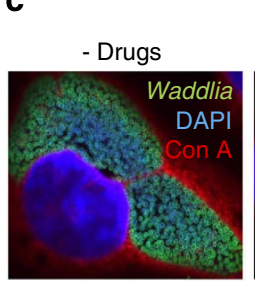

Phosphomycin $1,000 \mu \mathrm{g} \mathrm{ml}^{-1}$
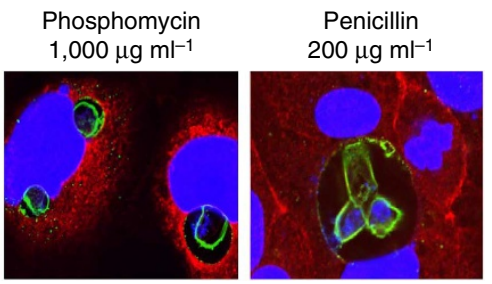

d

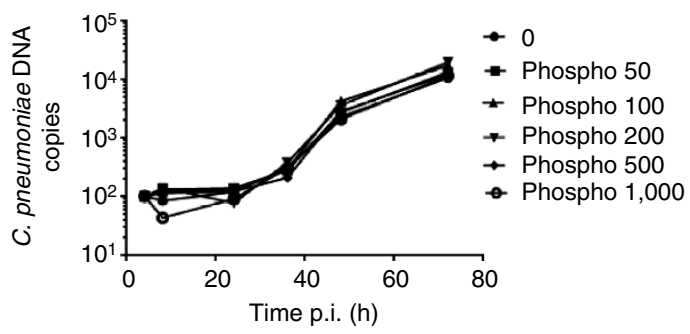

e

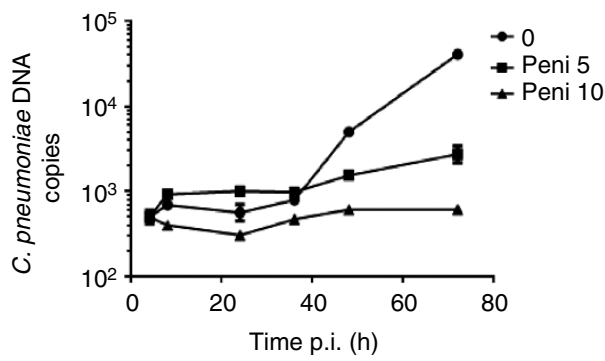

f
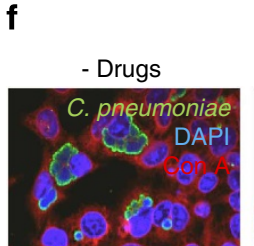

\section{Phosphomycin} $1,000 \mu \mathrm{g} \mathrm{ml}^{-1}$

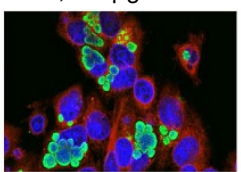

Penicillin $10 \mu \mathrm{g} \mathrm{ml}^{-1}$

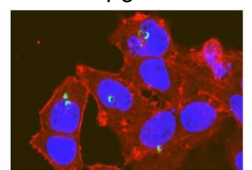

Septal localization of RodZ is prevented by phosphomycin. To explore whether the cell wall biosynthesis enzymes modulate the septal recruitment of RodZ or MreB in Chlamydiae, we first determined the effects of phosphomycin and penicillin (two PG biosynthesis inhibitors) on chlamydial division. Phosphomycin targets MurA, an UDP-N-acetylglucosamine enolpyruvyl transferase, while penicillin inhibits $\mathrm{Pbp} 2$ and $\mathrm{Pbp} 3$, two peptidoglycan-synthesizing transpeptidase homologues. C. trachomatis MurA is active in vitro and can substitute for E. coli MurA, but is resistant to phosphomycin ${ }^{44}$. In E. coli MurA, resistance to phosphomycin is conferred by a single Cys 115 to Asp mutation ${ }^{45}$, a mutation that is present in the MurA orthologues of the Chlamydiaceae, but not in W. chondrophila MurA (Supplementary Fig. 4), suggesting that W. chondrophila should be sensitive to phosphomycin. W. chondrophila encodes a betalactamase that should confer some resistance to penicillin derivatives $^{13}$. Nevertheless, we found that $W$. chondrophila cells are sensitive to each drug at concentrations higher than $100 \mu \mathrm{g} \mathrm{ml}^{-1}$ (Fig. 4a,b), preventing cytokinesis and inducing the formation of aberrant bodies (Fig. 4c). In comparison, there was no effect of phosphomycin on growth and morphology of C. pneumoniae (Fig. 4d,f), while penicillin had a strong effect on $C$. pneumoniae growth at much lower concentrations (5-10 $\mathrm{g} \mathrm{ml}^{-1}$, Fig. 4e). The penicillin derivatives mecillinam (targeting specifically $\mathrm{Pbp} 2$ ) and piperacillin (acting on $\mathrm{Pbp} 3$ ) partially block both $W$. chondrophila and C. pneumoniae infections (Supplementary Fig. 5A-G). This is consistent with a requirement of both $\mathrm{Pbps}$ in chlamydial division, as proposed for C. trachomatis $^{36}$. Taken together, these results confirm that the PG biosynthesis pathway is essential for proper growth of the Chlamydiales.

Next, we determined the effect of inhibiting PG biosynthesis on septal localization of MreB and RodZ. To this end, we treated infected cells $2 \mathrm{~h}$ p.i. with phosphomycin or penicillin and immunostained cells for RodZ and MreB in the resulting aberrant bodies at $24 \mathrm{~h}$ p.i. Phosphomycin, but not penicillin, caused a loss of septal localization of RodZ (Fig. 5 and Supplementary

Figure 4 | Phosphomycin and penicillin block growth of $\boldsymbol{W}$. chondrophila and induce aberrant bodies formation, but only penicillin has an effect on C. pneumoniae. (a) Waddlia DNA replication rate is lower in the presence of phosphomycin. Vero cells infected with $W$. chondrophila were harvested at different time points post infection with or without treatment with phosphomycin (50-1,000 $\mathrm{g} \mathrm{ml}^{-1}$ ), DNA was extracted and Waddlia DNA was quantified by qPCR. (Error bars represent the s.d. of three independent experiments). (b) Waddlia DNA replication rate is lower in the presence of penicillin. Waddlia-infected Vero cells were treated with $0-200 \mu \mathrm{g} \mathrm{ml}^{-1}$ of penicillin $2 \mathrm{~h}$ post infection, DNA was extracted at the given time points and Waddlia DNA was quantified by qPCR. (c) High concentrations of phosphomycin and penicillin induce the formation of aberrant bodies in W. chondrophila. Infected Vero cells were fixed and stained with anti-Waddlia antibodies (green), concanavalin A (red) and DAPI (blue). Confocal microscopy was performed $48 \mathrm{~h}$ p.i. in absence or presence of the indicated drugs. (d) C. pneumoniae is resistant to phosphomycin. Hep-2 cells were infected with $C$. pneumoniae. Phosphomycin (50-1,000 $\mathrm{g} \mathrm{ml}^{-1}$ ) was added $2 \mathrm{~h}$ post-infection. DNA was extracted the indicated time points and C. pneumoniae DNA was quantified by qPCR. (e) C. pneumoniae is sensitive to penicillin. Hep-2 cells were infected with C. pneumoniae and 5$10 \mu \mathrm{g} \mathrm{ml}^{-1}$ penicillin was added $2 \mathrm{~h}$ post-infection. DNA was extracted at the indicated time points and C. pneumoniae DNA was quantified by qPCR. (f) C. pneumoniae morphology is not affected by high concentrations of phosphomycin, but aberrant bodies are formed after treatment with penicillin. Hep-2 cells were treated as in d,e. After $24 \mathrm{~h}$, they were fixed and labelled with DAPI, anti-chlamydial LPS antibody (green) and concanavalin A (red) and observed by confocal microscopy. 
a

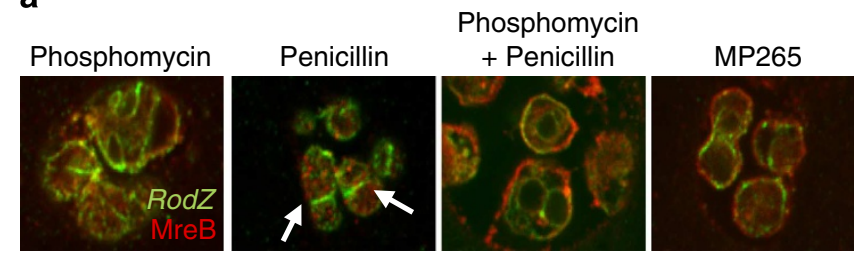

b

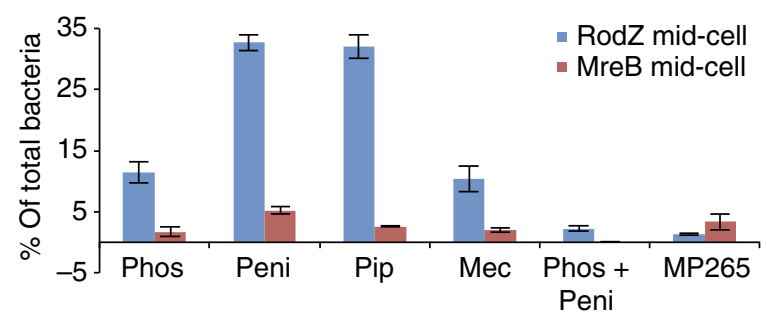

Figure 5 | Effect of phosphomycin, penicillin and MP265 on the localization of RodZ and MreB. (a) Localization of RodZ and MreB in presence of different drugs. Vero cells infected with $W$. chondrophila were treated with the indicated drugs $2 \mathrm{~h}$ p.i. $\left(500 \mu \mathrm{g} \mathrm{ml}^{-1}\right.$ phosphomycin, $500 \mu \mathrm{gl}^{-1}$ penicillin or $100 \mu \mathrm{g} \mathrm{ml}^{-1} \mathrm{MP265}$ ). Cells were fixed $24 \mathrm{~h}$ p.i., labelled with antibodies against RodZ (green) and MreB (red) and observed by confocal microscopy. Arrows show the accumulation of RodZ at midcell. (b) Quantification of the accumulation of RodZ and MreB at the bacterial mid-cell by confocal microscopy after treatment with $500 \mu \mathrm{g} \mathrm{ml}^{-1}$ phosphomycin (Phospho), $500 \mu \mathrm{g} \mathrm{ml}^{-1}$ penicillin (Peni), $500 \mu \mathrm{g} \mathrm{ml}^{-1}$ piperacillin (Pip), $500 \mu \mathrm{g} \mathrm{ml}^{-1}$ mecillinam (Mec) and $100 \mu \mathrm{g} \mathrm{ml}{ }^{-1} \mathrm{MP} 265$ $(n=100)$. (Error bars represent the s.d. of three independent experiments).

Fig. $5 \mathrm{H}-\mathrm{K})$. After penicillin treatment, more than $30 \%$ of aberrant bodies were partially constricted and showed a strong septal localization of RodZ (Fig. 5, arrows). Septal RodZ and cell constriction were rarely seen after phosphomycin treatment (in $12.3 \%$ of counted bacteria, Fig. 5). Interestingly, piperacillin but not mecillinam had a similar effect on RodZ localization as penicillin (Fig. 5b and Supplementary Fig. 5L,M). This indicates that $\mathrm{Pbp} 3$, rather than $\mathrm{Pbp} 2$, plays a role in the recruitment of the Waddlia division machinery and that its inhibition causes an accumulation of septal RodZ. Moreover, MurA acts upstream of Pbps to localize RodZ to the septum because addition of both phosphomycin and penicillin together results in a similar localization defect of RodZ as phosphomycin alone (Fig. 5). This is consistent with the fact that MurA is also biochemically upstream of Pbps in the PG biosynthetic pathway. Interestingly, addition of MP265 also blocks RodZ accumulation (Fig. 5). Thus, RodZ depends on MreB to reach the septum or to be retained at this site (see discussion).

\section{Discussion}

While the organization of the chlamydial division septum has remained mysterious in the past, our study makes three major contributions in illuminating the spatiotemporal mechanisms of chlamydial division. First, we unearth RodZ and MreB as the first known septal proteins, with RodZ being an early recruit while MreB follows later. Second, we show that cell wall precursor synthesis and trans-peptidation are required for the septal localization of RodZ and its subsequent dispersion. Finally, we show that cell wall precursor synthesis (lipid II) is required for division in $W$. chondrophila, suggesting that cell wall promotes constriction. The finding that MreB is involved in the division of Waddlia chondrophila and Chlamydia pneumoniae, two distant members of the Chlamydiales order, is supported by the strong conservation of MreB, by its localization at the periphery of the cell and by its enrichment at the division furrow. A potential role of MreB in the division of C. trachomatis was already proposed by Ouellette and colleagues ${ }^{36}$, based on A22/MP265-treated C. trachomatis cells. We extend these pharmacological results by showing that A22/MP265 also impairs division of $W$. chondrophila and C. pneumoniae. Importantly, we bolster these findings by showing that MreB localizes to deeply constricted septa. As $\mathrm{MreB}$ is not recruited to the division septum early, it does not seem to function as an organizer of early division events as would be expected from a functional homologue of FtsZ. By contrast, we observed an early localization of RodZ to the division septum and an intricate dependence of its localization on the function of PG biosynthesis enzymes in Chlamydiales. Given the ability of RodZ to directly interact with monomeric and filamentous $\mathrm{MreB}^{33,34,46-48}$, we speculate that RodZ could function as the division organizer, tracking or being transported along actin-like filaments of MreB to reach and ultimately mark the future division site. The RodZ protein is usually composed of three conserved domains: a $\mathrm{N}$-terminal essential domain, a transmembrane domain and a dispensable C-terminal domain ${ }^{39}$. The chlamydial RodZ, which exhibits only a low similarity to E. coli RodZ (24-30\%, Supplementary Fig. 6A), has a predicted transmembrane domain but completely lacks the C-terminal domain (Supplementary Fig. 6B). The C-terminal part of RodZ is not essential for RodZ localization but is important for its function and stability ${ }^{39}$. Thus, the finding that MreB inhibitors impair RodZ localization to the septum suggests direct interactions between RodZ and MreB; however, indirect explanations are also possible (see below).

Recently, it was hypothesized that Chlamydiales synthesize a modified version of PG from Lipid II without glycans ${ }^{21}$. We took advantage of the sensitivity of $W$. chondrophila to phosphomycin to test whether MurA, a critical enzyme in PG precursor biosynthesis, is required for chlamydial division. Inhibition of MurA with phosphomycin inhibits cytokinesis, resulting in the formation of large, round and unconstricted aberrant bodies, resembling the treatment with the penicillin derivatives that inhibit Pbps. When Pbp3 is inhibited, aberrant bodies with a partial contraction at mid-cell are visible. Finally, when MreB is blocked, partial contraction of aberrant bodies is visible, but RodZ does not accumulate at mid-cell. Thus, MurA, Pbp2 and MreB all seem to be required for proper localization of $\operatorname{RodZ}$ at the division septum, while $\mathrm{Pbp} 3$ is responsible for a later event that leads to the contraction of the septum and the disassembly of RodZ. This interpretation is strengthened by the result that MurA acts upstream of the Pbps in the W. chondrophila cell wall biosynthesis, because cotreatment with phosphomycin and penicillin causes a phenotype similar to phosphomycin alone. Spatial cues could be provided by enzymes responsible for the synthesis of lipid II, including particularly those that are known to interact with chlamydial MreB such as MurG, MurF and/or $\mathrm{MraY}^{35}$, or other proteins that act in an early step of PG biosynthesis ${ }^{46}$. Our result that lipid II plays a key role in the (direct or indirect) organization of the chlamydial division septum is reminiscent of the role of staphylococcal cell wallassociated teichoic acids in organizing division and is in agreement with an unpublished report that $\mathrm{Pbp} 1 \mathrm{~A}$ and $\mathrm{Pbp} 2 \mathrm{X}$ are delocalized from the streptococcal division septum by the lipid II-sequestering antibiotic nisin ${ }^{47}$.

Taken together, our results show the importance of cell wall precursors for the organization of the division septum in $W$. chondrophila. We took advantage of the rapid growth of $W$. chondrophila, of the bigger size of its cells and of its sensitivity to phosphomycin to perform this study. The resistance of 
Chlamydiaceae to phosphomycin would not have allowed the investigation of the importance of PG in the division of these bacteria. However, PG precursor biosynthesis is conserved among Chlamydiales (Supplementary Tables 1 and 2), indicating that our results might be representative of a common mechanism among all Chlamydiales.

\begin{abstract}
Methods
Antibodies, probes and reagents. Polyclonal mouse and rabbit antibodies against $W$. chondrophila were produced in-house as previously described ${ }^{48}$. Antibodies against actin were purchased from Sigma-Aldrich (St Louis, MO). MitoTracker Red CMXRos (M7512) as well as secondary antibodies Alexa Fluor 488 goat anti-rabbit, 488 anti-mouse, 594 anti-rabbit and 594 anti-mouse were all obtained from Molecular Probes (Grand Island, NY). A22, phosphomycin, penicillin, mecillinam and piperacillin were purchased from Sigma-Aldrich. MP265 was synthesized by American Custom Chemicals Corporation (San Diego, CA). Vero cells were treated with $10 \mu \mathrm{M}$ nocodazole (Sigma-Aldrich) or $10 \mu \mathrm{M}$ cytochalasin D (Sigma-Aldrich). Primers and probes used in this study are described in supplementary Table 3.
\end{abstract}

Strains and growth conditions. E. coli EC100D (Epicentre Technologies, Madison, WI) and Rosetta (DE3)/pLysS (Novagen, Madison, WI) were grown in Luria Bertani broth (LB). Caulobacter crescentus NA1000 (ref. 49) and derivatives were grown at $30^{\circ} \mathrm{C}$ in PYE (peptone-yeast extract) or PYE supplemented with either $0.3 \%$ xylose (PYEX) or $0.2 \%$ glucose (PYEG).

W. chondrophila ATCC VR- $1470^{\mathrm{T}}$ was grown using the amoeba Acanthamoeba castellanii ATCC 30010 cultivated in $25 \mathrm{~cm}^{2}$ cell-culture flasks with $10 \mathrm{ml}$ peptoneyeast extract-glucose medium. The flasks were incubated for 6 days at $28^{\circ} \mathrm{C}$, cell suspension was collected and filtered through a $5-\mu \mathrm{m}$-pore filter to retain amoebae and to purify bacteria in the flow-through.

C. pneumoniae ATCC VR-1310 was grown using Hep-2 cells cultivated in 24 well-plates (Corning, NY) with $1 \mathrm{ml}$ DMEM containing $10 \%$ fetal calf serum (FCS), $1 \%$ amino-acid mix, $1 \%$ vitamin mix and $2 \mu \mathrm{g} / \mathrm{ml}$ of cycloheximide (Life technologies, Carlsbad, CA). The flasks were incubated for $72 \mathrm{~h}$ at $37^{\circ} \mathrm{C}$ in presence of $5 \% \mathrm{CO}_{2}$. Cells were then resuspended and homogenized with glass beads.

Cell culture and bacterial infection. Vero cells (ATCC CCL-81) were grown in $75 \mathrm{~cm}^{2}$ flasks with $20 \mathrm{ml}$ DMEM containing $10 \%$ fetal calf serum at $37^{\circ} \mathrm{C}$ in presence of $5 \% \mathrm{CO}_{2}$. Hep-2 cells (ATCC CCL23) were grown in $75 \mathrm{~cm}^{2}$ flasks with $20 \mathrm{ml}$ DMEM containing $10 \%$ fetal calf serum, $1 \%$ non-essential amino-acid mix, $1 \%$ vitamin mix and $2 \mu \mathrm{g} \mathrm{ml}^{-1}$ of cycloheximide at $37^{\circ} \mathrm{C}$ in presence of $5 \% \mathrm{CO}_{2}$.

Overnight cell cultures containing originally $10^{5}$ cells per ml were infected with a 2,000 $\times$ dilution of $W$. chondrophila or a $10 \times$ dilution of C. pneumoniae (MOI of 1-2). The cells were then centrifuged for $15 \mathrm{~min}$ (W. chondrophila) or $30 \mathrm{~min}$ (C. pneumoniae) at $1,790 \mathrm{~g}$, incubated $15 \mathrm{~min}$ at $37^{\circ} \mathrm{C}$, washed with PBS before addition of fresh media.

Immunofluorescence labelling. Infected Vero or Hep-2 cells on coverslips were fixed with ice-cold methanol for $5 \mathrm{~min}$ at room temperature or with $4 \%$ paraformaldehyde for $15 \mathrm{~min}$. Mitotracker staining was performed on living cells before fixation following the manufacturer's protocol (Molecular Probes). After fixation, cells were washed three times with PBS. Cells were then blocked and permeabilized for at least $1 \mathrm{~h}$ with a blocking buffer (PBS, $0.1 \%$ saponin, $1 \%$ BSA). Coverslips were then incubated with 1:100 dilutions of primary antibodies directed against bacteria or the actin of the host diluted in blocking buffer for $1 \mathrm{~h}$ at room temperature. After three washes with PBS containing 0.1\% saponin, coverslips were incubated with 1:1,000 dilutions of secondary antibodies in blocking buffer containing DAPI (Molecular Probes). Coverslips were washed three times with PBS containing 0.1\% saponin, once with PBS and once with water. Subsequently, they were mounted onto glass slides using Mowiol

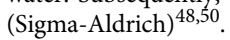

Confocal and fluorescence microscopy. Infection rate, inclusions and aberrant bodies were quantified by fluorescence microscopy by counting a minimum of hundred cells in duplicate. Images were taken by confocal microscopy using a Zeiss LSM 510 Meta (Zeiss, Oberkochen, Germany). Images were then treated and quantified using the ImageJ software (http://www.macbiophotonics.ca).

Quantitative PCR. Infection was quantified by real-time PCR. At different time points after infection, infected cells were resuspended by scrapping. Genomic DNA was extracted from $50 \mu \mathrm{l}$ of cell suspension using the Wizard SV Genomic DNA purification system (Promega, Madison, WI). Elution was processed with $200 \mu \mathrm{l}$ of water. Quantitative real-time PCR was performed using iTaq supermix with ROX (BioRad, Hercules, CA). To detect W. chondrophila, $200 \mathrm{nM}$ of primers WadF4 and WadR4, $100 \mathrm{nM}$ of probe WadS2 (ref. 51) and $5 \mu \mathrm{l}$ of DNA were used. For C. pneumoniae detection, $550 \mathrm{nM}$ of primers $\mathrm{CpnF}$ and CpnR, and $100 \mathrm{nM}$ of probe CpnS were used ${ }^{52}$. Cycling conditions were $3 \mathrm{~min}$ at $95^{\circ} \mathrm{C}$ followed by
40 cycles of $15 \mathrm{~s}$ at $95^{\circ} \mathrm{C}$ and $1 \mathrm{~min}$ at $60^{\circ} \mathrm{C}$ for both PCRs. A stepOne Plus Realtime PCR System (Applied Biosystems, Carlsbad, CA) was used for amplification and detection of the PCR products.

RNA extraction, cDNA synthesis and qPCR. Five hundred microlitres of infected cell culture was taken at the given time points, mixed with $1 \mathrm{ml}$ of RNA Protect (Qiagen, Venlo, Netherlands), mixed and incubated for $5 \mathrm{~min}$ at room temperature. The suspension was then centrifuged for $10 \mathrm{~min}$ at $5,000 \mathrm{~g}$, the supernatant was removed and the pellet was frozen at $-80^{\circ} \mathrm{C}$. The pellet was then unfrozen, and RNA was extracted using the RNeasy Plus kit (Qiagen). DNA contamination was removed by DNAse digestion, using Ambion DNA-free kit (Life technologies, Grand Island, NY).

cDNA was then synthesized by reverse transcription using a Goscript Reverse Transcription System (Promega, Fishburg, WI). qPCR was performed by adding $4 \mu \mathrm{l}$ of cDNA to $10 \mu \mathrm{l}$ of iTaq Universal SYBR Green mix (BioRad, Hercules, CA), $4.8 \mu \mathrm{l}$ of water and $0.6 \mu \mathrm{l}$ of each specific forward and reverse primers targeting the $16 \mathrm{~S}$ rRNA gene, $m r e B$ or rodZ. Cycling conditions were $3 \mathrm{~min}$ at $95^{\circ} \mathrm{C}$ followed by $45 \mathrm{cycles}$ of $15 \mathrm{~s}$ at $95^{\circ} \mathrm{C}$ and $1 \mathrm{~min}$ at $60^{\circ} \mathrm{C}$. A stepOne Plus Real-time PCR System (Applied Biosystems, Carlsbad, CA) was used for amplification and detection of the PCR products.

Protein extraction, SDS-PAGE, western blot. Five-hundred microlitres of infected cell culture were harvested at different time points. Cells were harvested, and proteins were extracted by resuspension in loading buffer $(60 \mathrm{mM}$ Tris $\mathrm{pH} 6.8$, $1 \%$ SDS, $1 \%$ mercaptoethanol, $10 \%$ glycerol, $0.02 \%$ bromophenol blue). Ten microlitres of the suspension was loaded on a $12.5 \%$ polyacrylamide gel. After $45 \mathrm{~min}$ migration at $200 \mathrm{~V}$, proteins were transferred onto a nitrocellulose membrane by electroblotting at $75 \mathrm{~V}$ for $1 \mathrm{~h}$. The membrane was blocked with $5 \%$ milk for $2 \mathrm{~h}$ and then incubated for at least $2 \mathrm{~h}$ with a 1:2,500 dilution of rabbit antibody directed against heat-inactivated $W$. chondrophila. An incubation of $2 \mathrm{~h}$ with a 1:2,500 dilution of a HRP-conjugated goat anti-rabbit antibody was then performed. Detection of HRP was done using $0.03 \%$ hydrogen peroxide, $220 \mu \mathrm{g} \mathrm{ml}^{-1}$ luminol and $32.5 \mu \mathrm{g} \mathrm{ml}^{-1}$ coumaric acid in $0.1 \mathrm{M}$ Tris $\mathrm{pH}$ 8.5. Chemiluminescence was recorded with the ImageQuant LAS 4000 Mini imager (GE healthcare, Waukesha, WI). Images were then treated using ImageJ. Uncropped version of the Western blot is provided in the Supplementary Fig. 3B.

Electron microscopy. Vero and Hep-2 cells were infected as described above. Infected cells were collected $24 \mathrm{~h}$ p.i. and fixed in $2 \%$ paraformaldehyde and $0.1 \%$ glutaraldehyde for $45 \mathrm{~min}$. Samples were then treated for $1 \mathrm{~h}$ at room temperature with $1 \%$ osmium tetroxide in PBS and then washed several times in increasing acetone concentrations $(50-100 \%)$. Samples were resuspended for $1 \mathrm{~h}$ in acetoneepon and overnight in epon and finally embedded using an epoxy resin (Fluka). Embedded blocks were then sliced with a LKB 2088 Ultratome microtome, placed on formvar-coated copper grids (Sigma-Aldrich) and stained for $10 \mathrm{~min}$ with methanol-uranyl acetate and lead nitrate with sodium citrate in water ${ }^{48}$. The resulting sections were examined with a Philips CM-100 transmission electron microscope.

Bioinformatic studies. Identity values were obtained using BLASTP version 2.2.25 with an expectation value threshold of 0.1 . If necessary, the average identity of multiple High-Scoring segment Pair (HSP) was weighted according to the length of each HSP. Protein sequences were aligned using Tcoffee ${ }^{53}$. The computational analyses were performed at the Vital-IT (http://www.vital-it.ch) Center for highperformance computing of the Swiss Institute of Bioinformatics (SIB).

Amphipathic helixes prediction was done using the online program Amphipaseek (http://npsa-pbil.ibcp.fr/ $/)^{54}$. Topology and transmembrane domain prediction was performed using the online program TMHMM Server (http://www.cbs.dtu.dk/ services/TMHMM/)

Cell viability. Viability of the host cells in presence of the different drugs was determined using the Resazurin kit (Sigma-Aldrich). Cells were incubated for $24 \mathrm{~h}$ in presence of the drugs. Resazurin was added in an amount equal to $10 \%$ of the culture volume. Cells were then incubated at $37^{\circ} \mathrm{C}$ for $4 \mathrm{~h}$. Absorbance was then measured using the FLUOstar Omega microplate reader (BMG Labtech, Offenburg, Germany).

MreB expression, purification and antibody production. $m r e B^{W c}$ was amplified from $W$. chondrophila ATCC VR-1470 (ref. 13) genomic DNA by using primers $m r e B \_N d e$ and $m r e B \_E c o$. The product was digested with NdeI and EcoRI restriction endonucleases (Roche, Basel, Switzerland) and the reaction purified with QIAquick Gel extraction kit (QIAgen, Venlo, The Netherlands). The purified $m r e B^{W c}$ was ligated into the expression vector pMT335 (ref. 55) restricted with NdeI and EcoRI. Recombinant plasmids were introduced in E. coli EC100D by electroporation. The construct was verified by sequencing (Fasteris, Geneva, Switzerland). His $_{6}-$ SUMO-MreB $^{W c}$ was expressed in pCWR547 in E. coli Rosetta $(\mathrm{DE} 3) / \mathrm{pLysS}$ and purified under denaturing conditions (in $8 \mathrm{M}$ UREA standard 
procedures, QIAgen, Hilden, Germany). In brief, cells were inoculated in 11 of LB and grown at $30^{\circ} \mathrm{C}$ until they reached an $\mathrm{OD}_{600}=\sim 0.4$. One millimolar IPTG was added to the culture and then grown at $30^{\circ} \mathrm{C}$ for $3 \mathrm{~h}$. Cells were pelleted and resuspended in $25 \mathrm{ml}$ of lysis buffer $(10 \mathrm{mM}$ Tris $\mathrm{HCl} \mathrm{pH8}, 0.1 \mathrm{M} \mathrm{NaCl}, 1 \mathrm{mM}$ $\beta$-mercaptoethanol, $5 \%$ glycerol, $0.5 \mathrm{mM}$ imidazole, triton $0.02 \%$ ). Cells were sonicated (Sonifier Cell Disruptor B-30; Branson Sonic Power, Danbury, CT) on ice using 20 bursts of $20 \mathrm{~s}$ at output level 5.5. After centrifugation at 6,000 r.p.m. for $20 \mathrm{~min}$ at $4{ }^{\circ} \mathrm{C}$, the supernatant was discarded while the pellet was resuspended in buffer B ( $8 \mathrm{M}$ Urea, $0.1 \mathrm{M} \mathrm{NaH}_{2} \mathrm{PO}_{4}, 0.1 \mathrm{M}$ Tris- $\mathrm{HCl}$, $\mathrm{pH}$ 8.0). The resulting suspension was centrifuged for $20 \mathrm{~min}$ at 6,000 r.p.m. at $4{ }^{\circ} \mathrm{C}$. The supernatant was loaded onto a column containing $5 \mathrm{ml}$ of Ni-NTA agarose resin. Column was rinsed with buffer $\mathrm{B}$ and buffer $\mathrm{C}\left(8 \mathrm{M}\right.$ Urea, $0.1 \mathrm{M} \mathrm{NaH}_{2} \mathrm{PO}_{4}, 0.1 \mathrm{M}$ Tris- $\mathrm{HCl}, \mathrm{pH}$ 6.3). $\mathrm{His}_{6}-\mathrm{SUMO}-\mathrm{MreB}^{W c}$ was eluted in buffer $\mathrm{E}$ (8 M Urea, $0.1 \mathrm{M} \mathrm{NaH}_{2} \mathrm{PO}_{4}$, $0.1 \mathrm{M}$ Tris- $\mathrm{HCl}, \mathrm{pH} 4.5$ ). The protein was then excised from a $12.5 \% \mathrm{SDS}$ polyacrylamide gel and used to immunize New Zealand white rabbits (Josman LLC, Napa, CA).

RodZ expression, purification and antibody production. The ORF corresponding to RodZ (ORF wcw_0755) was amplified by PCR using the primers RodZ_fwd and RodZ_rev and cloned into the pET200 vector (Life technologies) in E. coli. This vector allows the expression of a N-terminal tagged version of the protein under a isopropyl- $\beta$-D-thiogalactopyranoside (IPTG) inducible promoter. Protein was expressed with $1 \mathrm{mM}$ IPTG (MP Biomedicals, Santa Ana, CA) during $4 \mathrm{~h}$ and purified in presence of $8 \mathrm{M}$ urea. Bacteria were lysed using Fastbreak Lysis buffer (Promega). Lysate was then incubated with MagneHis Ni particles beads and beads were washed with binding/wash buffer (Promega). The purified protein was then eluted using $500 \mathrm{mM}$ imidazole (Sigma-Aldrich) ${ }^{56}$. The purified protein was then used to immunize mice (Eurogentec, Seraing, Belgium).

Membrane fractionation. Waddlia-infected Vero cells were harvested and resuspended in $500 \mathrm{ml}$ of $10 \mathrm{mM}$ EDTA at $\mathrm{pH} 9.5$ and incubated for $2 \mathrm{~h}$ at $37^{\circ} \mathrm{C}$. Membrane and cytosol fractions were separated by ultracentrifugation for $1 \mathrm{~h}$ at $100,000 \mathrm{~g}$. The membrane and cytosol fraction were boiled in sample buffer and analysed by western blot.

\section{References}

1. Greub, G. The medical importance of Chlamydiae. Clin. Microbiol. Infect. 15, 2-3 (2009).

2. Rurangirwa, F. R., Dilbeck, P. M., Crawford, T. B., McGuire, T. C. \& McElwain, T. F. Analysis of the 16S rRNA gene of micro-organism WSU 86-1044 from an aborted bovine foetus reveals that it is a member of the order Chlamydiales: proposal of Waddliaceae fam. nov., Waddlia chondrophila gen. nov., sp. nov. Int. J. Syst. Bacteriol. 49(Pt 2): 577-581 (1999).

3. Baud, D., Thomas, V., Arafa, A., Regan, L. \& Greub, G. Waddlia chondrophila, a potential agent of human fetal death. Emerg. Infect. Dis. 13, 1239-1243 (2007).

4. Baud, D., Regan, L. \& Greub, G. Emerging role of Chlamydia and Chlamydialike organisms in adverse pregnancy outcomes. Curr. Opin. Infect. Dis. 21, 70-76 (2008).

5. Baud, D. et al. Waddlia chondrophila: from bovine abortion to human miscarriage. Clin. Infect. Dis. 52, 1469-1471 (2011).

6. Friis, R. R. Interaction of L cells and Chlamydia psittaci: entry of the parasite and host responses to its development. J. Bacteriol. 110, 706-721 (1972).

7. Greub, G. \& Raoult, D. Crescent bodies of Parachlamydia acanthamoeba and its life cycle within Acanthamoeba polyphaga: an electron micrograph study. Appl. Environ. Microbiol. 68, 3076-3084 (2002).

8. Abdelrahman, Y. M. \& Belland, R. J. The chlamydial developmental cycle. FEMS. Microbiol. Rev. 29, 949-959 (2005).

9. Goy, G., Croxatto, A. \& Greub, G. Waddlia chondrophila enters and multiplies within human macrophages. Microbes. Infect. 10, 556-562 (2008).

10. Goy, G. \& Greub, G. Antibiotic susceptibility of Waddlia chondrophila in Acanthamoeba castellanii amoebae. Antimicrob. Agents. Chemother. 53, 2663-2666 (2009).

11. Kebbi-Beghdadi, C., Batista, C. \& Greub, G. Permissivity of fish cell lines to three Chlamydia-related bacteria: Waddlia chondrophila, Estrella lausannensis and Parachlamydia acanthamoebae. FEMS. Immunol. Med. Microbiol. 63, 339-345 (2011).

12. Kebbi-Beghdadi, C., Cisse, O. \& Greub, G. Permissivity of Vero cells, human pneumocytes and human endometrial cells to Waddlia chondrophila. Microbes. Infect. 13, 566-574 (2011).

13. Bertelli, C. et al. The Waddlia genome: a window into chlamydial biology. PLoS ONE 5, e10890 (2010).

14. Wientjes, F. B. \& Nanninga, N. Rate and topography of peptidoglycan synthesis during cell division in Escherichia coli: concept of a leading edge. J. Bacteriol. 171, 3412-3419 (1989).

15. Pilhofer, M. et al. Discovery of chlamydial peptidoglycan reveals bacteria with murein sacculi but without FtsZ. Nat. Commun. 4, 2856 (2013).
16. Liechti, G. W. et al. A new metabolic cell-wall labelling method reveals peptidoglycan in Chlamydia trachomatis. Nature 506, 507-510 (2013).

17. Fox, A. et al. Muramic acid is not detectable in Chlamydia psittaci or Chlamydia trachomatis by gas chromatography-mass spectrometry. Infect. Immun. 58, 835-837 (1990).

18. Ghuysen, J. M. \& Goffin, C. Lack of cell wall peptidoglycan versus penicillin sensitivity: new insights into the chlamydial anomaly. Antimicrob. Agents Chemother. 43, 2339-2344 (1999).

19. McCoy, A. J. \& Maurelli, A. T. Characterization of Chlamydia MurC-Ddl, a fusion protein exhibiting D-alanyl-D-alanine ligase activity involved in peptidoglycan synthesis and D-cycloserine sensitivity. Mol. Microbiol. 57, 41-52 (2005).

20. McCoy, A. J. \& Maurelli, A. T. Building the invisible wall: updating the chlamydial peptidoglycan anomaly. Trends Microbiol. 14, 70-77 (2006).

21. Henrichfreise, B. et al. Functional conservation of the lipid II biosynthesis pathway in the cell wall-less bacteria Chlamydia and Wolbachia: why is lipid II needed? Mol. Microbiol. 73, 913-923 (2009).

22. Brown, W. J. \& Rockey, D. D. Identification of an antigen localized to an apparent septum within dividing chlamydiae. Infect. Immun. 68, 708-715 (2000).

23. Matsumoto, A. \& Manire, G. P. Electron microscopic observations on the effects of penicillin on the morphology of Chlamydia psittaci. J. Bacteriol. 101, 278-285 (1970).

24. Kazar, J., Gillmore, J. D. \& Gordon, F. B. Effect of Interferon and interferon inducers on infections with a nonviral intracellular microorganism, Chlamydia trachomatis. Infect. Immun. 3, 825-832 (1971).

25. Coles, A. M., Reynolds, D. J., Harper, A., Devitt, A. \& Pearce, J. H. Low-nutrient induction of abnormal chlamydial development: a novel component of chlamydial pathogenesis? FEMS Microbiol. Lett. 106, 193-200 (1993).

26. Raulston, J. E. Response of Chlamydia trachomatis serovar E to iron restriction in vitro and evidence for iron-regulated chlamydial proteins. Infect. Immun. 65, 4539-4547 (1997).

27. Mpiga, P. \& Ravaoarinoro, M. Chlamydia trachomatis persistence: an update Microbiol. Res. 161, 9-19 (2006).

28. Kirkpatrick, C. L. \& Viollier, P. H. New(s) to the (Z-)ring. Curr. Opin. Microbiol. 14, 691-697 (2011).

29. Stephens, R. S. et al. Genome sequence of an obligate intracellular pathogen of humans: Chlamydia trachomatis. Science 282, 754-759 (1998).

30. Chastanet, A. \& Carballido-Lopez, R. The actin-like MreB proteins in Bacillus subtilis: a new turn. Front. Biosci. 4, 1582-1606 (2012).

31. Bendezu, F. O., Hale, C. A., Bernhardt, T. G. \& de Boer, P. A. RodZ (YfgA) is required for proper assembly of the MreB actin cytoskeleton and cell shape in E. coli.. EMBO J. 28, 193-204 (2009).

32. Shiomi, D. \& Niki, H. A mutation in the promoter region of zipA, a component of the divisome, suppresses the shape defect of RodZ-deficient cells. Microbiologyopen 2, 798-810 (2013).

33. Figge, R. M., Divakaruni, A. V. \& Gober, J. W. MreB, the cell shapedetermining bacterial actin homologue, co-ordinates cell wall morphogenesis in Caulobacter crescentus. Mol. Microbiol. 51, 1321-1332 (2004).

34. Fenton, A. K. \& Gerdes, K. Direct interaction of FtsZ and MreB is required for septum synthesis and cell division in Escherichia coli. EMBO J. 32, 1953-1965 (2013).

35. Gaballah, A., Kloeckner, A., Otten, C., Sahl, H. G. \& Henrichfreise, B. Functional analysis of the cytoskeleton protein MreB from Chlamydophila pneumoniae. PLoS ONE 6, e25129 (2011).

36. Ouellette, S. P., Karimova, G., Subtil, A. \& Ladant, D. Chlamydia co-opts the rod shape-determining proteins $\mathrm{MreB}$ and $\mathrm{Pbp} 2$ for cell division. Mol. Microbiol. 85, 164-178 (2012).

37. Defeu Soufo, H. J. \& Graumann, P. L. Dynamic localization and interaction with other Bacillus subtilis actin-like proteins are important for the function of MreB. Mol. Microbiol. 62, 1340-1356 (2006).

38. van den Ent, F., Johnson, C. M., Persons, L., de Boer, P. \& Lowe, J. Bacterial actin MreB assembles in complex with cell shape protein RodZ. EMBO J. 29, 1081-1090 (2010).

39. Alyahya, S. A. et al. RodZ, a component of the bacterial core morphogenic apparatus. Proc. Natl Acad. Sci. USA 106, 1239-1244 (2009).

40. Mohammadi, T. et al. The essential peptidoglycan glycosyltransferase MurG forms a complex with proteins involved in lateral envelope growth as well as with proteins involved in cell division in Escherichia coli. Mol. Microbiol. 65, 1106-1121 (2007).

41. van den Ent, F., Amos, L. A. \& Lowe, J. Prokaryotic origin of the actin cytoskeleton. Nature 413, 39-44 (2001).

42. Salje, J., van den Ent, F., de Boer, P. \& Lowe, J. Direct membrane binding by bacterial actin MreB. Mol. Cell. 43, 478-487 (2011).

43. Gitai, Z., Dye, N. A., Reisenauer, A., Wachi, M. \& Shapiro, L. MreB actinmediated segregation of a specific region of a bacterial chromosome. Cell $\mathbf{1 2 0}$, 329-341 (2005). 
44. McCoy, A. J., Sandlin, R. C. \& Maurelli, A. T. In vitro and in vivo functional activity of Chlamydia MurA, a UDP-N-acetylglucosamine enolpyruvyl transferase involved in peptidoglycan synthesis and fosfomycin resistance. J. Bacteriol. 185, 1218-1228 (2003).

45. Kim, D. H. et al. Characterization of a Cys115 to Asp substitution in the Escherichia coli cell wall biosynthetic enzyme UDP-GlcNAc enolpyruvyl transferase (MurA) that confers resistance to inactivation by the antibiotic fosfomycin. Biochemistry 35, 4923-4928 (1996).

46. Rueff, A. S. et al. An early cytoplasmic step of peptidoglycan synthesis is associated to MreB in Bacillus subtilis. Mol. Microbiol. 91, 348-362 (2013).

47. Pinho, M. G., Kjos, M. \& Veening, J. W. How to get (a)round: mechanisms controlling growth and division of coccoid bacteria. Nat. Rev. Microbiol. 11, 601-614 (2013).

48. Croxatto, A. \& Greub, G. Early intracellular trafficking of Waddlia chondrophila in human macrophages. Microbiology 156, 340-355 (2010).

49. Evinger, M. \& Agabian, N. Envelope-associated nucleoid from Caulobacter crescentus stalked and swarmer cells. J. Bacteriol. 132, 294-301 (1977).

50. Greub, G., Mege, J. L., Gorvel, J. P., Raoult, D. \& Meresse, S. Intracellular trafficking of Parachlamydia acanthamoebae. Cell. Microbiol. 7, 581-589 (2005).

51. Goy, G., Croxatto, A., Posfay-Barbe, K. M., Gervaix, A. \& Greub, G. Development of a real-time PCR for the specific detection of Waddlia chondrophila in clinical samples. Eur. J. Clin. Microbiol. Infect. Dis. 28, 1483-1486 (2009).

52. Welti, M. et al. Development of a multiplex real-time quantitative PCR assay to detect Chlamydia pneumoniae, Legionella pneumophila and Mycoplasma pneumoniae in respiratory tract secretions. Diagn. Microbiol. Infect. Dis. 45, 85-95 (2003).

53. Notredame, C., Higgins, D. G. \& Heringa, J. T-Coffee: A novel method for fast and accurate multiple sequence alignment. J. Mol. Biol. 302, 205-217 (2000).

54. Sapay, N., Guermeur, Y. \& Deleage, G. Prediction of amphipathic in-plane membrane anchors in monotopic proteins using a SVM classifier. BMC Bioinformatics 7, 255 (2006).

55. Thanbichler, M., Iniesta, A. A. \& Shapiro, L. A comprehensive set of plasmids for vanillate- and xylose-inducible gene expression in Caulobacter crescentus. Nucleic Acids Res. 35, e137 (2007).
56. Greub, G. et al. High throughput sequencing and proteomics to identify immunogenic proteins of a new pathogen: the dirty genome approach. PLoS ONE 4, e8423 (2009).

\section{Acknowledgements}

This study was supported by the 2011 Leenaards foundation prize. We thank S. Aeby for technical support, the PFMU at the Medical Faculty of Geneva for preparation of electron microscopy samples, B. M. Humbel and C. Loussert from the Electron Microscopy Facility of the University of Lausanne for assisting with electron microscopy analyses as well as the Cellular Imaging Facility platform of the University of Lausanne for confocal microscopy.

\section{Author contributions}

N.J. performed the chlamydial infection experiments, immunofluorescence, confocal microscopy and electron microscopy and drafted the manuscript. A.F. performed the protein purification and C. crescentus experiments. T.P. participated in the sequence alignments. P.V. and G.G. designed the study and participated in the redaction of the manuscript. All authors read and approved the final manuscript.

\section{Additional information}

Supplementary Information accompanies this paper at http://www.nature.com/ naturecommunications

Competing financial interests: The authors declare no competing financial interests.

Reprints and permission information is available online at http://npg.nature.com/ reprintsandpermissions/

How to cite this article: Jacquier, N. et al. Cell wall precursors are required to organize the chlamydial division septum. Nat. Commun. 5:3578 doi: 10.1038/ncomms4578 (2014).

(c) This work is licensed under a Creative Commons Attributioncc. NonCommercial-NoDerivs 3.0 Unported License. The images or other third party material in this article are included in the article's Creative Commons license, unless indicated otherwise in the credit line; if the material is not included under the Creative Commons license, users will need to obtain permission from the license holder to reproduce the material. To view a copy of this license, visit http://creativecommons.org/licenses/by-nc-nd/3.0/ 


\section{Corrigendum: Cell wall precursors are required to organize the chlamydial division septum}

Nicolas Jacquier, Antonio Frandi, Trestan Pillonel, Patrick H. Viollier \& Gilbert Greub

Nature Communications 5:3578 doi: 10.1038/ncomms4578 (2014); Published 8 Apr 2014; Updated 30 Jul 2014

In the original version of this Article, the middle initial of the author Patrick H. Viollier was omitted from the author information. This has now been corrected in both the PDF and HTML versions of the Article. 